\title{
Reform in Teaching of Projective Comprehensive Training of Higher Vocational Mathematics Based on Capstone Course Theory
}

\author{
Xincheng Wang \\ Wenzhou Vocational \& Technical College, Wenzhou 325035, China \\ E-mail: wxc_zjh@126.com
}

\begin{abstract}
At this stage, the Chinese higher occupation education has transferred from quantity expansion to quality improvement. The training goals of higher occupation education are more clear and accurate. In this process, the higher vocational mathematics education is as a public basic course, how to adapt and serve the construction of the quality of higher vocational talents, is the subject of urgent research. From the perspective of capstone course theory, Reform in Teaching of projective comprehensive training of Higher Vocational Mathematics based on capstone course theory is more close to the actual, and more emphasis on the comprehensive professional ability and the application of knowledge, and it has the relatively unique meaning, multiple goals, flexible implementation mode, such that it has important practical significance on the quality of the current higher vocational mathematics teaching construction and curriculum reform.
\end{abstract}

Keywords- higher vocational education; mathematics teaching; comprehensive training; reform of teachin

\section{INTRODUCTION}

In the past ten years, with the rapid development of China's economy, the occupation education accordingly has been vigorously developed. It is as the following symbols, i.e., the implementation of the Ministry high teaching education [2006]16 document and the construction of national demonstration vocational colleges, the higher vocational education in our country starts from the phase scale of expansion of the transfer into the stage of connotation development [1].

In regard to its meaning, occupation education (Vocational Education) is to train skilled persons, for a particular occupation technology, operating personnel, it is based on the occupation, ability oriented education. Higher vocational education is not directly involved in the design, planning, decision-making, but takes the technology talents into a real product or produces the technical talents of the specific role on social operation. Higher vocational education should aim at training the technology applied talents in the era of knowledge economy.

Mathematics course is as a public basic course in higher vocational colleges, how to better the professional course study, how to play its due role in the realization of the goal of training the vocational talents, is the current reform of mathematics teaching in the subject of urgent research.

\section{PROBLEMS AND COUNTERMEASURES OF HIGHER VOCATIONAL MATHEMATICS TEACHING}

The higher occupation education has two basic attributes: education and vocation. In higher education, it is the type of occupation education; in the occupation education, the level of it is higher education. Higher education is reflected in the general properties, higher vocational education must have the attributes of higher education. Pay attention to the basic knowledge, theory and skill and focus on the sustainable development of education. The vocational education reflected in paying attention to practical ability and analysis and the ability in solving the practical problems [2].

In the current higher education, two levels of understanding are as follows. One is too much emphasis on higher education of vocational education. In the process of personnel training, it emphasizes the theory teaching partly, views the vocational as undergraduate "compressed biscuits". In mathematics teaching, it still use the undergraduate teaching concept, simplified version of the materials used in undergraduate textbooks and the teaching methods used in the analysis of undergraduate teaching method. To stress the integrity theory, it focuses on the derivation of theorem and problem solving skills, methods. But in the popularization of higher education, higher vocational enrollment diversification, diversification of school background, high use of undergraduate teaching methods are not only unrealistic, but also difficult to adapt to the diverse needs of their students. Such teaching, teachers may feel tired, the students are bitter. The result is as follows: it not only hurt the teachers' teaching enthusiasm, but also makes the students' confidence be hurt, even conflicted emotions in learning advanced mathematics. Eventually the teaching effect is little, and it is difficult to realize the target of talent training.

The other is too much emphasis on vocational education vocational education, one-sided emphasis on practical ability, excessive reduction or even cancellation on necessary theory courses, downing level on vocational education. In the higher mathematics teaching, it almost deletes all theories; examples are just simply copy the formula, no analysis and thorough, slightly deeper problems to solve by using mathematical software. The result is as follows: one is not to play functions of mathematical education in logical thinking training. The other one is that the understanding of the concept is not transparent, lack of necessary theoretical analysis, and the mathematical model is difficult to establish the actual problem, 
even it cannot apply the mathematical knowledge to solve practical problems.

In view of the existing problems in higher mathematics teaching, learning American capstone course theory, based on the learning of basic mathematics theory, and reforming the mathematics teaching to train the comprehensive project, are not only the effective solutions to solve the mathematics and professional, mathematics and application of line, but also the route to improve the students' interest in learning and to enhance students' comprehensive ability.

\section{CONNOTATION OF CAPSTONE COURSE}

The capstone course is a new course education in the curriculum reform of American University at the end of the twentieth century. The more authoritative definition is given by scholars Toure, "The capstone course is located in the terminal of course series, and to integrate the relative fragments of knowledge into a whole as target 'crowning' courses or experiences." Therefore, the capstone course is a specific course, is also a new type of course. The main connotations are as follows.

First of all, the capstone course emphasis on mastering knowledge for the students' previous knowledge, transferring the knowledge into ability, and remodeling the knowledge structure of students. It is not only to impart the knowledge and skills of a subject or a professional.

Secondly, the capstone course emphasizes the integration of theory with practice, not to learn theoretical knowledge only, but to combine the knowledge and skills with the practical work and social demand.

Thirdly, the capstone course is a course of knowledge, critical reflection and expansion.

Fourth, the capstone courses not only concerns about the traditional intellectual skills, pays attention to the hard abilities of students' finding and solving practical problems, but also pay attention to soft students' abilities of communication, organization, cooperation, soft power.

\section{BASIC CONCEPTS OF PROJECT TEACHING}

The so-called project teaching is the sum of a series of teaching methods according to the education goal by an education, which uses the project case as the basic teaching material, introduce learners to practice situation, and construct equal dialogue and positive research and other forms through interactive between teachers and students, among students, so as to improve the education ability decision making ability and behavior of the learners in the face of the complex situation [3].

Compared with the traditional teaching and project teaching, both of them have the advantages and disadvantages. Both of the two teaching have interrelated and obvious differences, the list is as follows.
TABLE I. STYLES DIFFERENCES OF TRADITIONAL TEACHING AND PROJECT TEACHING

\begin{tabular}{|c|c|c|}
\hline Category & traditional teaching & project teaching \\
\hline $\begin{array}{c}\text { teaching } \\
\text { objectives }\end{array}$ & $\begin{array}{c}\text { Pay attention to } \\
\text { knowledge learning }\end{array}$ & $\begin{array}{c}\text { Focus on the key } \\
\text { ability }\end{array}$ \\
\hline $\begin{array}{c}\text { teaching } \\
\text { material }\end{array}$ & $\begin{array}{c}\text { Complete knowledge } \\
\text { system }\end{array}$ & $\begin{array}{c}\text { The independent } \\
\text { practice projects }\end{array}$ \\
\hline $\begin{array}{c}\text { The status of } \\
\text { students }\end{array}$ & Passive to accept & initiative participation \\
\hline $\begin{array}{c}\text { communication } \\
\text { mode }\end{array}$ & $\begin{array}{c}\text { One dimensional } \\
\text { communication }\end{array}$ & $\begin{array}{c}\text { Multi-dimensional } \\
\text { communication }\end{array}$ \\
\hline $\begin{array}{c}\text { learning } \\
\text { interest }\end{array}$ & Low interest & high interest \\
\hline $\begin{array}{c}\text { teaching } \\
\text { methods }\end{array}$ & systematic teaching & $\begin{array}{c}\text { Discuss in } \\
\text { participation }\end{array}$ \\
\hline
\end{tabular}

From the comparison, we can find that the two teachings have different advantages and disadvantages. Therefore, in mathematics teaching of higher vocational education, the two should be combined with each other in the application. Firstly, the students can master the necessary theoretical knowledge in a short time in the traditional teaching. Then at the end of the course, we employ the project teaching to complete integration, internalization of knowledge.

\section{NECESSITY OF INTRODUCING THE PROJECT TEACHING}

Project teaching, from the comprehensive ability to improve students' interest in learning, enhance students' application of theoretical knowledge to solve practical problems and develop students' self perspective to learn knowledge, is very necessary and urgent.

First of all, the teaching reform project of comprehensive training puts up the bridge of theory and practice, mathematics and professional. It highlights and strengthens the application of mathematics, and enhances the comprehensive ability of students to solve the problems by means of analysis.

Secondly, because of the diversity of higher vocational students, the vocational college student lacks of interest to learning theory knowledge, the effect is more outstanding in mathematics learning. How to improve the interest in learning of mathematics in higher vocational colleges is the problem, which is urgent problem in the teaching reform of higher vocational mathematics. Compared with the project teaching and traditional teaching, the fundamental change has taken place in the teaching material. It is no longer a traditional knowledge from books, but is from the living and procreative practice, which is easy to stimulate the students' interest in learning mathematics.

Finally, in the network information age, the students have the ability to obtain information by using network. They are of personal independence of conduct and personality, who like the independent learning. Compared with the traditional teacher centered model, the students receive knowledge in a passive mode of teaching art, and more likely to participate equally in the teaching practice. While the project teaching just needs the students to make full use of information resources, access to information. Through the analysis, discussion, verification and evaluation, they are finally to solve practical problems.

Project teaching, as a teaching method, is an effective means and carrier, which is to cultivate the students' creative 
thinking, form the team spirit and improve the ability to solve practical problems. Through the implementation of teaching mathematics project, it makes the mathematics and professional, life and production practice combine closely, provide strong support for the professional and improve the ability to solve practical problems. At the same time, it can also promote the students to develop the habit of autonomous learning, and lay a solid foundation for future sustainable development.

\section{THE IMPLEMENTATION STEPS OF THE PROJECTIVE TEACHING OF THE HIGHER MATHEMATICS}

The teaching reform is in higher vocational mathematics of comprehensive projective training, which is the deepening and development of mathematics teaching reform of higher vocational education. The reform in higher vocational college is on the basis of original theoretical mathematics study by the students. In addition, it develops teaching on arranging a suitable time, and arrangements and professional, production, some comprehensive decision-making related to joint training project, through the thought of mathematical modeling and for guidance method, to inquiry teaching team. Compared with the traditional theory of science, the process can be divided into pre-class preparation stage, implementation stage and summary stage after class teaching. But because of the differences in teaching purpose, content, methods and means, the specific process of the three stages is different.

\section{A. The Preparation Stage before Class}

The pre-class preparation includes the preparations of teacher and the preparing of students.

The preparing of teachers before class mainly is the selection of the comprehensive training project. To select the project, teachers should do the following two points. First, teachers need a deep understanding of the related background knowledge of students' learning, try to select a typical project that comes from a professional, production, management. Second, the comprehensive projects are moderate difficulty. The selected item should be divided into several problems, from easy to difficult. The students can solve one part, through discussion and cooperation, and solve the difficult part under the guidance of teachers.

As for students, because of the practical problems and without artificial processing too much, it will inevitably involve professional concept. The students need to access the information, understand the relevant background knowledge, and cultivate the college Students' use of resources and the ability and habit of autonomous learning.

\section{B. The Implementation Stage of Teaching}

Firstly, according to the students' actual situation and ability, we need to use the group as a unit to complete project.

Secondly, in the process of teaching, teachers no longer play a leading role, but should play the leading role. Students are no longer of passive acceptance of knowledge, but use the project as a carrier and with the necessary theoretical knowledge, supplemented by related mathematical software, to solve problems actively. In some sense, " projective teaching" is the capstone course of higher vocational mathematics.
The main task of project teaching is not to let the students learn new professional knowledge and skills, but to promote the past knowledge and skills integration, synthesis. In this process, students are the active implementation of integration, synthesis. The role of the teacher is no longer the control knowledge, teaching, but the facilitator of students learning. Its main task is to promote the students to change from dependent learners to self-directed learning (self-directed). As to the vertex class teaching, teachers should pay special attention to the motivation of reward, initiative creativity, and training or coax students from across the traditional highly structured classroom environment to dynamic environmental [4].

Finally, in the process of the teaching project, when students encounter a problem, teachers are not simply tell the results, but through the students' discussion, teachers can guide, lead to further close the problem step by step in truth.

\section{The Summing Stage after Class}

The last link of project teaching that summarize the appraisal link is often overlooked. After the summary, it is an important link in the integration and improvement of knowledge of the students.

First of all, through panel presentations, reporting the completion of project, it can improve the learning process of the students' knowledge. At the same time, it also can exercise the students' capability in language organization and expression.

Secondly, through summing up, the teachers comment the completing project for the student, point out their advantages and one's own knack, and enhance the self-confidence of students, so as to make students understand that mathematics is useful and make them solve the practical problems by using mathematical knowledge. The teachers should point out the insufficient place and make students understand that the mathematical knowledge of their own is not enough. To solve practical problems, it needs more mathematics knowledge to form a virtuous circle of learning mathematics.

Finally, by comparison to select the winner, promote students to form a benign interactive and competition environment in learning.

\section{PROJECT ANALYSIS}

The matching loan and owing problem: a couple decides to buy a house by loan. The monthly interest rate $r=0.005$, now they plan to loan 1000000 Yuan from the bank, according to the way f monthly matching repayment, 20 years to pay off (usually referred to the monthly). If the monthly income of a couple in addition to the normal expenditure, and the balance of 10000 Yuan, then the question is that is this couple's plan feasible?

The project is closely integrated with the business of professional project case, and also has extensive background application. At first, the students need to understand the various interests bearing of bank lending and their applicable scope of business. Secondly, students should know the calculation principle of matching repayment, and then know the formula. Through accessing to information, there are three interest- 
bearing ways, simple interest, compound interest, continuous compounding interest.

Through accessing the information, students can give a comprehensive understanding on various settlement ways of business, and know about the matching owing on the loan for the power of compound interest method.

Denote $P_{0}$ as the principal, $n$ as the settlement period. Suppose the monthly repayment amount is $x$, before a thorough analysis of its mechanism by the students, a simple calculation by group is as follows:

$$
x=\frac{P_{0}(1+r)^{n}}{n}=13792.5
$$

For such a conclusion, the students will be discussed; the repayment is about 3000000 approximate 20 years. Obviously it is a little too high. Then the teacher can properly guide: due to the repayment for each month, so the principal decreases. Not all of the principal are based on the settlement of 20 years. Through the guidance, it can cause the students' interest in learning. Then the students can found in the online settlement formula. But in order to make the students better understand the principle of settlement, the teacher can further guide.

For such a conclusion, the students will be discussed, approximate 20 years repayment about 3000000 , obviously is a little too. Then the teacher can properly guide: because the repayment each month, so the principal in the decreasing. Not all of the principal is based on 20 years of settlement. Through the guidance, caused the student interest in learning, students can also be found in the online settlement formula. But in order to make students better understand the settlement principle, the teacher can further guide:

Put the principal of 1000000 Yuan into 240 parts: $x_{1}, x_{2}, \cdots \cdots, x_{240}$, it satisfies as follows:

$$
x_{1}(1+r)=x \quad, \quad x_{2}(1+r)^{2}=x \quad \ldots \quad x_{240}(1+r)^{240}=x .
$$

Using the geometric series of $n$ terms and the formulas are derived as follows.

$$
x=\frac{r(1+r)^{n} p}{(1+r)^{n}-1}=7164.31
$$

On this basis, we can further expand the project. By introducing the concepts of the "discount" and "discount" in the economics, we can further discuss two questions in the college mathematical modeling at 2000 and 2011: the optimized fund and the balanced pension payments.

\section{CONCLUSIONS}

The rise of Higher Vocational Education in China is only a short period of ten years, relative to the educational development and precipitation, the time is too short. As public basic course of mathematical education, from the curriculum to teaching reform, it just at the beginning, is still at the attempt and exploration stage. At the same time, in reference to some successful experience, we should pay more attention to some new trend of the current reform of mathematics teaching, do it from now and face it in the future.

With the continuous development of higher vocational education, as a mathematics course in higher vocational public class, its teaching purpose and teaching effect should push indepth study and serve the realization of training objective in mathematics teaching reform of higher vocational education. The projective teaching is a comprehensive practice, which is also a measure in teaching reform and identical to the training goal of higher vocational talents. Therefore, the teaching reform of comprehensive projective practice training is a concerned trend of teaching reform of higher mathematics.

\section{REFERENCES}

[1] DIN G Jin-chang. Research and Practice of Sustainable Development of Higher Vocational Education based on Three Traits[J], Journal of Higher Education, 2010,31(6):72-77.

[2] DIN G Jin-chang. Study on Talent Quality of Higher Vocational Education[J], China Higher Education Research, 2011, 1: 68-69.

[3] HU Zhen-yuan. Research on Teaching Case of Mathematics in Higher Vocational Colleges[D], Shandong Normal University, 2007:4-11.

[4] LIU Xiao-qiang1 JIANG Xi-feng. Curriculum Reform under the Quality Strategy Case Study of Capstone Courses in American Universities[J], Tsinghua Journal of Education, 31(2):69-76. 